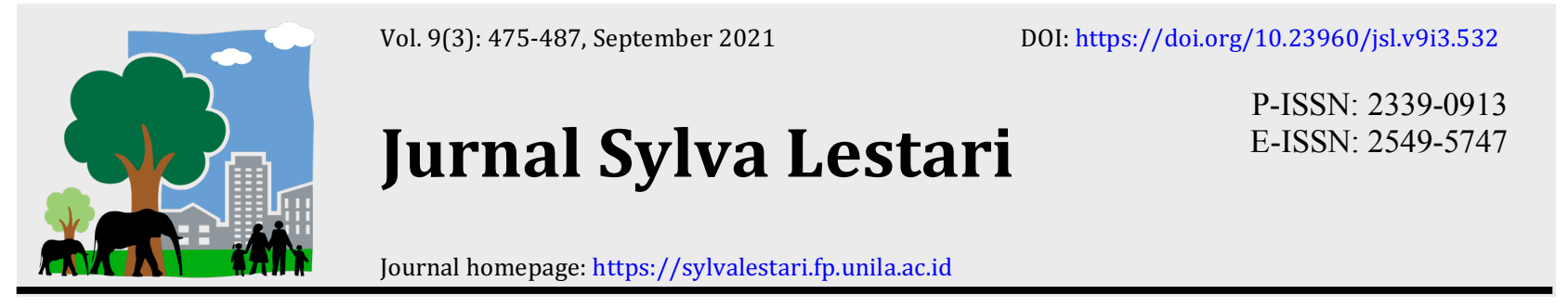

Full Length Research Article

\title{
Effects of Strands Pre-treatment and Adhesive Type on the Properties of Oriented Strand Board Made from Gmelina (Gmelina arborea) Wood
}

Siti Aisyah ${ }^{1}$, Januar Haryadi ${ }^{1}$, Muhammad Iqbal Maulana ${ }^{1}$, Marwanto ${ }^{1}$, Denni Prasetia ${ }^{2}$, Wahyu Hidayat ${ }^{3}$, Muhammad Adly Rahandi Lubis ${ }^{4}$, Nam Hun Kim ${ }^{2, *}$, Fauzi Febrianto, ${ }^{1, * *}$

${ }^{1}$ Department of Forest Products, Faculty of Forestry and Environment, IPB University. Jl. Ulin, Kampus IPB Darmaga Bogor, 16680, Bogor, Indonesia

2 Department of Forest Materials Engineering, College of Forest and Environmental Sciences, Kangwon National University. Chuncheon, 24341, Republic of Korea

${ }^{3}$ Department of Forestry, Faculty of Agriculture, University of Lampung. Jl. Sumantri Brojonegoro 1, Bandar Lampung, 35145, Indonesia

${ }^{4}$ Research Center for Biomaterials, National Research and Innovation Agency. Jl. Raya Jakarta-Bogor Km.46, Cibinong, Bogor, 16911, Indonesia

* Corresponding Author. E-mail address: kimnh@kangwoon.ac.kr

${ }^{* *}$ Corresponding Author. E-mail address: febrianto76@yahoo.com

\section{ARTICLE HISTORY}

Received: 15 July 2021

Peer review completed: 9 November 2021

Received in revised form: 14 November 2021 Accepted: 18 November 2021

\section{KEYWORDS:}

Gmelina

Methylene diphenyl diisocyanate

Oriented strand board

Phenol-formaldehyde

Steam treatment
(C) 2021 The Author(s). Published by Department of Forestry, Faculty of

Agriculture, University of Lampung in collaboration with Indonesia Network for Agroforestry Education (INAFE)

This is an open access article under the CC BY-NC license:

https://creativecommons.org/licenses/by$\mathrm{nc} / 4.0 /$

\begin{abstract}
The objective of this study was to evaluate the effects of steam treatment of strands on the physical and mechanical properties of oriented strand board (OSB) from gmelina wood (Gmelina arborea) bonded with two types of adhesive. Strands of gmelina wood were steamed at $126^{\circ} \mathrm{C}$ and pressure of $0.14 \mathrm{MPa}$ for $1 \mathrm{~h}$. OSBs were prepared with a $0.6 \mathrm{~g} / \mathrm{cm}^{3}$ target density using two types of adhesives, namely methylene diphenyl diisocyanate (MDI) and phenol-formaldehyde (PF) resins. The resin content used was $5 \%$ for MDI and $10 \%$ for PF. The physical and mechanical properties of the OSB were evaluated referring to the JIS A 5908-2003 standard, and the values were compared with CSA 0437.0 (Grade O-1) standard. The results showed that the steam treatment improved the dimensional stability of OSB, as shown from the decrease of water absorption and thickness swelling. Steam treatment also increased the mechanical properties of the OSB, such as modulus of elasticity, modulus of rupture, internal bonding strength, and screw holding power. The results revealed that gmelina wood OSB bonded with MDI adhesives produced better OSB than bonded with PF resin.
\end{abstract}

\section{Introduction}

Recently, plantation forests have been the primary source of wood supplies for the timber industry. Plantation forests supplied about $85 \%$ of logs of the total timber production in Indonesia. The log production from plantation forests in 2016-2018 increased from 32.2 million $\mathrm{m}^{3}$ to 40.9 million $\mathrm{m}^{3}$ (MOEF 2021). Wood from plantation forests is generally fast-growing species such as acacia (Acacia mangium), sengon (Paraserianthes falcataria), and gmelina (Gmelina arborea). Gmelina is a species that is easy to cultivate and is prioritized in plantation forest development (Riyanto et al. 2013). Statistics Indonesia (2020) informed that gmelina wood production in 2019 reached 65.6 million $\mathrm{m}^{3}$. Gmelina wood has a specific gravity of $0.37-0.44$ with a strength class IV (Prabawa 2017). In addition, Moya and Leandro (2010) reported that gmelina wood has a large 
percentage of juvenile wood. These characteristics indicate that gmelina wood tends to be inferior for construction when it uses in solid form. Therefore, it is necessary to consider alternative uses of gmelina wood.

Wood-based composite products are the alternative in the utilization of fast-growing wood species. According to Iswanto et al. (2010), low to medium-density woods can be used as raw materials for oriented strand board (OSB). OSB is a composite product for structural uses. OSB is made from strands oriented perpendicular to each other between layers and held together using an exterior type adhesive at elevated temperature and high pressure (APA 2017). The quality of OSB is influenced by several factors such as wood species, strand geometry, layer ratio, board density, density profile, extractive substances, pre-treatment, and adhesive type (Adrin et al. 2013; Davinsy et al. 2019; Febrianto et al. 2017; Iswanto et al. 2010; Maulana et al. 2016, 2020, 2021). Pretreatment is intended to remove extractive substances that can inhibit the gluing process from increasing the adhesive penetration into the strands. Gmelina wood has a relatively high extractive content of $9.27 \%$ (Nurhasni et al. 2016). Therefore, pre-treatment on the gmelina strands before the manufacture of OSB is necessary. Previous studies reported that strands steam treatment at the temperature of $126^{\circ} \mathrm{C}$ under a pressure of $0.14 \mathrm{MPa}$ for $1 \mathrm{~h}$ could improve dimensional stability and some mechanical properties of the OSB (Febrianto et al. 2015; Maulana 2017). In addition, steam treatment could reduce the extractive substances and starch in strands (Fatrawana et al. 2019).

The type of adhesive can also affect the quality of the OSB (Febrianto et al. 2017). Phenolformaldehyde (PF) and methylene diphenyl diisocyanate (MDI) resins are generally used to manufacture OSB. According to Kang et al. (2017), PF resin is inexpensive and has good bond strength. However, PF resin has the disadvantage of being dark in color and producing formaldehyde emission (Sutrisno et al. 2015). On the other hand, MDI adhesive could produce better OSB properties than OSB bonded with PF (Adrin et al. 2013; Febrianto et al. 2015). However, MDI adhesive is expensive. The MDI adhesive forms urethane linkages from the reaction between isocyanate (-NCO) groups of MDI with wood hydroxyl (-OH) groups (Lubis et al. 2019), producing good adhesion and without formaldehyde emission (Langenberg et al. 2010). The use of gmelina wood as a raw material for manufacturing OSB could increase its utilization as a construction material. Based on the explanation above, it is essential to investigate the effect of steam treatment and adhesive type on the physical and mechanical properties of OSB manufactured using gmelina wood strands.

\section{Materials and Methods}

\subsection{Raw Material Preparation and Pre-treatment}

Eight-year-old gmelina wood from Bogor, West Java, Indonesia, was harvested and converted into strands with a length of $7 \mathrm{~cm}$, width of $2 \mathrm{~cm}$, and thickness of $0.1-0.2 \mathrm{~cm}$ using a disk flaker. The geometric characteristics of the gmelina strands are presented in Table 1. The strands were then air-dried for 14 days. Strand was steamed in an autoclave at $126^{\circ} \mathrm{C}$, under a pressure of $0.14 \mathrm{MPa}$ for $1 \mathrm{~h}$ (Maulana et al. 2017). After the steam treatment, strands were airdried and then oven-dried at $60^{\circ} \mathrm{C}$ until reach moisture content (MC) of less than $5 \%$. 
Table 1. Geometric characteristics of the gmelina strands

\begin{tabular}{lccccrc}
\hline \multirow{2}{*}{ Parameter } & \multicolumn{2}{c}{ Minimum } & \multicolumn{2}{c}{ Maximum } & \multicolumn{2}{c}{ Average } \\
& Steam & Control & Steam & Control & Steam & Control \\
\hline Length $(\mathrm{cm})$ & 5.53 & 6.00 & 7.47 & 7.00 & 6.40 & 6.55 \\
Width $(\mathrm{cm})$ & 1.70 & 1.88 & 2.65 & 2.54 & 2.17 & 2.22 \\
Thickness (cm) & 0.05 & 0.05 & 0.16 & 0.20 & 0.09 & 0.09 \\
Slenderness Ratio & 38.38 & 31.50 & 128.8 & 128.0 & 73.76 & 76.6 \\
Aspect Ratio & 2.40 & 2.58 & 4.32 & 3.51 & 2.97 & 2.96 \\
\hline
\end{tabular}

Note: Determined by measuring 100 strands selected randomly.

\subsection{Oriented Strand Board Manufacturing}

The boards were made with a dimension of $30 \mathrm{~cm} \times 30 \mathrm{~cm} \times 1 \mathrm{~cm}$ (length $\times$ width $\times$ thickness) and a target density of $0.6 \mathrm{~g} / \mathrm{cm}^{3}$. Two types of adhesive were used, namely MDI with 5\% adhesive content and PF with 10\% adhesive content (Adrin et al. 2013; Febrianto et al. 2009, 2012, 2015). The strands and adhesive were mixed using a spray gun in a rotary drum blender. Approximately $1 \%$ of paraffin was added to the strand and adhesive mixture. Strands were arranged into three layers with a face/core/back layer ratio of $1 / 2 / 1$, perpendicular to each other. The mats were hot-pressed with a specific pressure of $2.45 \mathrm{MPa}$ at a temperature of $150^{\circ} \mathrm{C}$ for 10 min. The boards were conditioned for \pm 14 days to release residual stresses and reach equilibrium MC. The board without steam treatment was made as a control. Fig. 1 shows the oriented strand board made from gmelina strands.

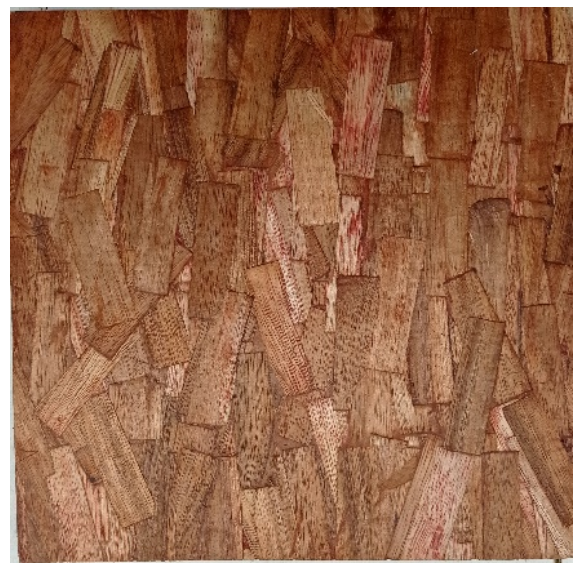

Fig. 1. Oriented strand board made from gmelina strands.

\subsection{Physical and Mechanical Properties Evaluation}

The testing of physical and mechanical properties of OSB refers to standard JIS A 5908:2003 (JSA 2003). The physical properties tested included density, water absorption, and thickness swelling after $24 \mathrm{~h}$ immersed in water. In contrast, the mechanical properties tested included modulus of elasticity, modulus of rupture, internal bonding strength, and screw holding power. Each value of physical and mechanical properties was then compared to commercial OSB standard CSA 0437.0 (Grade O-1) (SBA 2005).

\subsubsection{Density}

The samples of $10 \mathrm{~cm} \times 10 \mathrm{~cm} \times 1 \mathrm{~cm}$ (length $\times$ width $\times$ thickness) were measured in an airdried state to obtain its volume $(\mathrm{Va})$. The samples were then weighed to obtain air-dried weight $(W a)$. The density $(D)$ value of the sample was calculated using equation 1 . 


$$
D\left(g / \mathrm{cm}^{3}\right)=\frac{W a}{V a}
$$

\subsubsection{Water absorption}

The samples of $5 \mathrm{~cm} \times 5 \mathrm{~cm} \times 1 \mathrm{~cm}$ (length $\times$ width $\times$ thickness) were weighed $(W 1)$ and then immersed for $24 \mathrm{~h}$. After immersing, the samples were drained and weighed again $(W 2)$. The water absorption $(W A)$ value of the sample was calculated as follows:

$$
W A(\%)=\frac{W 2-W 1}{W 1} \times 100 \%
$$

\subsubsection{Thickness swelling}

The samples of $5 \mathrm{~cm} \times 5 \mathrm{~cm} \times 1 \mathrm{~cm}$ (length $\times$ width $\times$ thickness) were measured for their average thickness (T1) and then immersed for $24 \mathrm{~h}$. After immersing, samples were drained, and the average thickness was measured again (T2). The thickness swelling (TS) value of the sample was calculated using the following formula:

$$
T S(\%)=\frac{T 2-T 1}{T 1} \times 100 \%
$$

\subsubsection{Modulus of elasticity}

The samples of $20 \mathrm{~cm} \times 5 \mathrm{~cm} \times 1 \mathrm{~cm}$ (length $\times$ width $\times$ thickness) in both parallel and perpendicular to the grain directions were used. The test was carried out using Universal Testing Machine (UTM, Instron, United States) with a load speed of $10 \mathrm{~mm} / \mathrm{min}$ and a span length of 15 $\mathrm{cm}$. The modulus of elasticity $(M O E)$ value of the sample was calculated as follows:

$$
\operatorname{MOE}(M P a)=\frac{\Delta P L^{3}}{4 \Delta y b h^{3}}
$$

where $\Delta P$ is the load under proportion limit $(\mathrm{N}), L$ is span length $(\mathrm{mm}), \Delta y$ is deflection $(\mathrm{mm}), b$ is sample width $(\mathrm{mm})$, and $h$ is sample thickness $(\mathrm{mm})$.

\subsubsection{Modulus of rupture}

The modulus of rupture (MOR) testing was carried out together with the MOE testing. The loading was continued until the sample reached the maximum load $(P)$. The MOR value of the sample was calculated the following formula:

$$
\operatorname{MOR}(M P a)=\frac{3 P L}{2 b h^{2}}
$$

\subsubsection{Internal bonding strength}

The samples of $5 \mathrm{~cm} \times 5 \mathrm{~cm} \times 1 \mathrm{~cm}$ (length $\times$ width $\times$ thickness) were glued to two wooden blocks with epoxy adhesive and allowed to dry for $24 \mathrm{~h}$. The two blocks are pulled perpendicular to the surface of the sample at a load speed of $2 \mathrm{~mm} / \mathrm{min}$ until the maximum load. The internal bonding (IB) strength of the sample was calculated as follows:

$$
I B(M P a)=\frac{P}{b l}
$$

where $l$ is sample length ( $\mathrm{mm})$. 


\subsubsection{Screw holding power}

The screws of $2.7 \mathrm{~mm}$ in diameter and $16 \mathrm{~mm}$ long were inserted into $5 \mathrm{~cm} \times 5 \mathrm{~cm} \times 1 \mathrm{~cm}$ (length $\times$ width $\times$ thickness) samples until $8 \mathrm{~mm}$ depth. The SHP value is expressed by the maximum load achieved in kgf.

\subsection{Data Analysis}

The completely randomized factorial design with two factors, namely pre-treatment factor (steam and control) and adhesive types factor (MDI and PF), was used to analyze data. The analysis of variance (ANOVA) was tested at a 95\% confidence interval. Duncan's Multiple Range Test (DMRT) was then carried out to find out the levels that were significantly different. All data analyses were carried out using IBM SPSS Statistics 26 Software.

\section{Results and Discussion}

\subsection{Density}

The gmelina OSBs density ranged from $0.49-0.57 \mathrm{~g} / \mathrm{cm}^{3}$ (Fig. 2). Based on Maloney (1993), the OSBs manufactured are classified as medium density boards $\left(0.40-0.80 \mathrm{~g} / \mathrm{cm}^{3}\right)$. The analysis of variance (ANOVA) showed that the interaction of steam treatment and adhesive types had no significant effect on the OSB density value. These indicated that the density of gmelina OSBs is homogeneous. Heterogeneous OSB density could produce varied mechanical strength and dimensional stability of the board (Maulana et al. 2021).

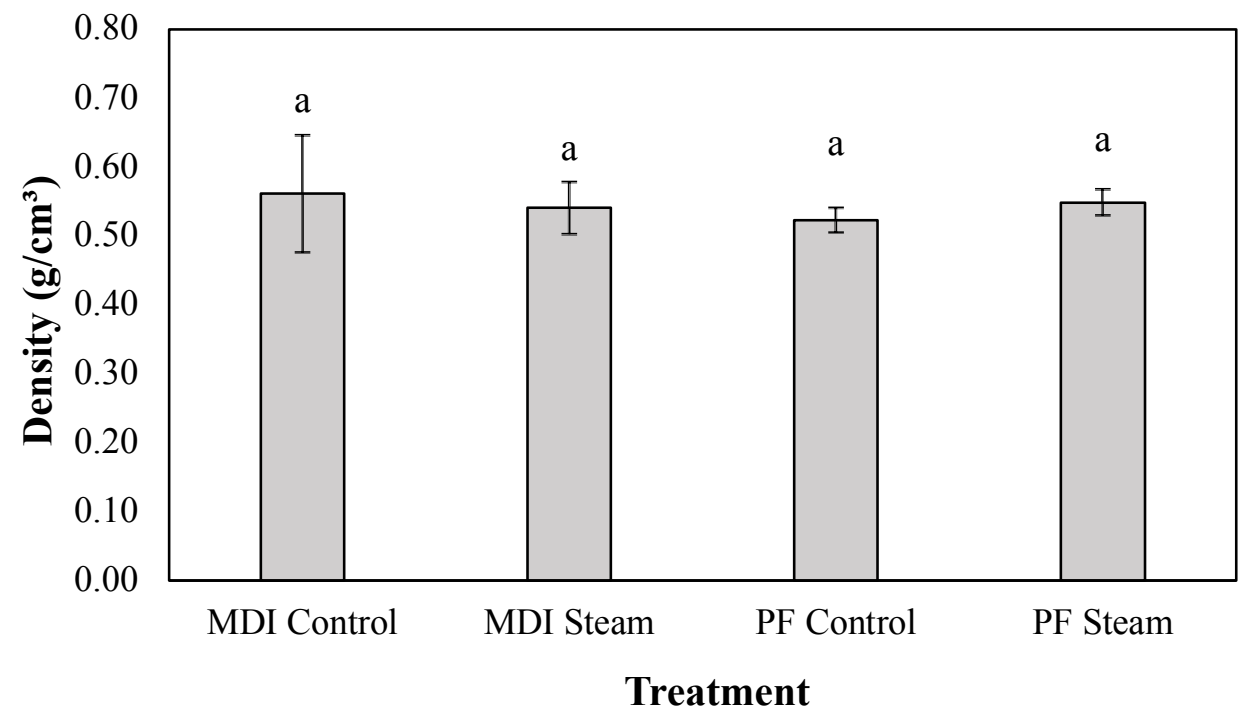

Fig. 2. The density value of gmelina OSBs on various treatments and adhesive types (Notes: the same letter showed no significant difference).

\subsection{Water Absorption}

The water absorption (WA) value of the OSBs ranged from $31.40-80.54 \%$ (Fig. 3). The highest WA value of gmelina OSBs was found in OSB bonded with PF adhesive without steam treatment, while the lowest was found in OSB bonded with MDI adhesive with steam treatment. The results of ANOVA showed that the interaction of treatment and adhesive types significantly affected the WA value of OSB. The Duncan's Multiple Ranged Test (DMRT) results showed that 
the WA value of each gmelina OSBs was significantly different. The WA value of gmelina OSBs bonded by MDI adhesive was lower than that bonded by PF resin. MDI adhesive has hydrophobic properties so that it absorbs less water and results in better board quality (Adrin et al. 2013). The WA value of steam-treated boards was lower than the control OSB for both adhesive types. Steam treatment could reduce the extractive content in the strands. Extractive content reduction led to lower water permeability of OSB, resulting in lower WA value of steam-treated OSB than control board (Fatrawana et al. 2019; Febrianto et al. 2017; Maulana et al. 2017).

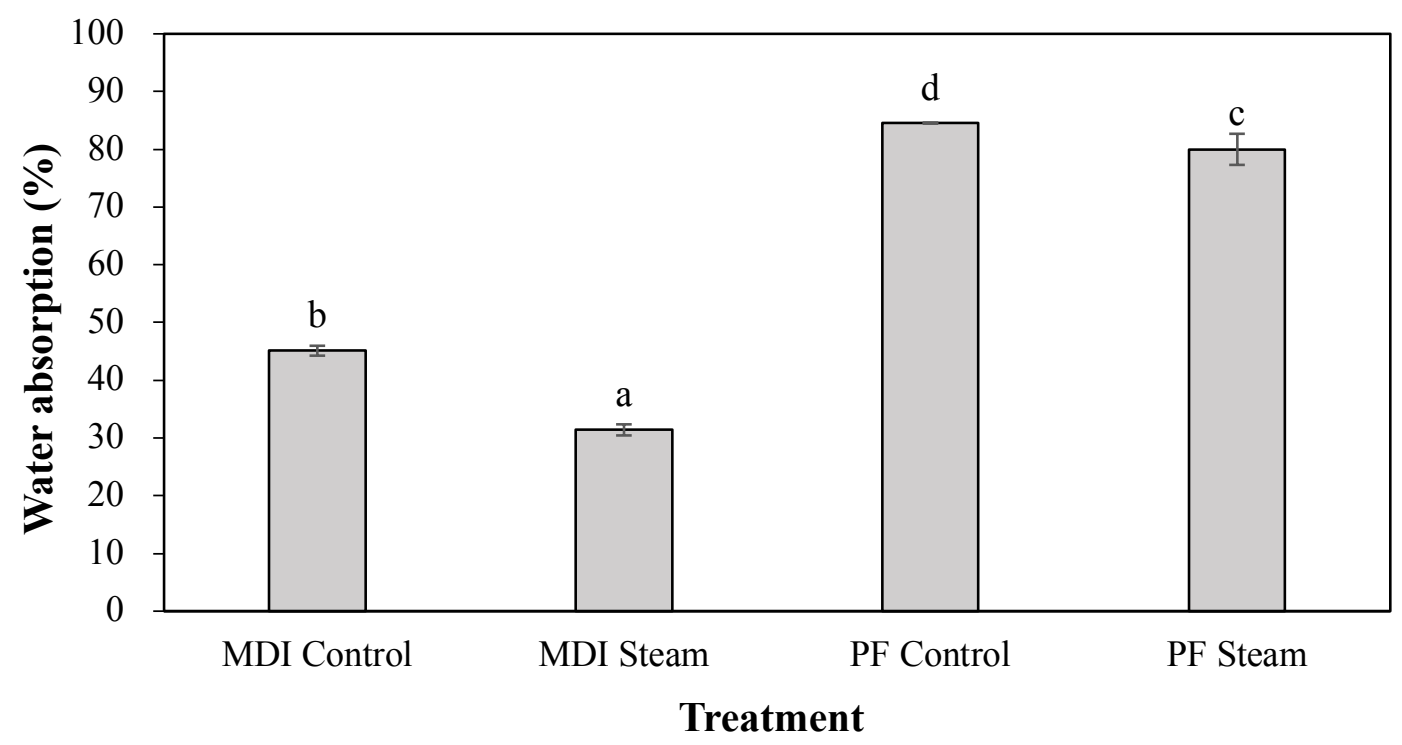

Fig. 3. The WA value of gmelina OSBs on various treatments and adhesive types (Notes: different letters showed a significant difference).

\subsection{Thickness Swelling}

The CSA 0437.0 (Grade O-1) standard required a thickness swelling (TS) value of OSB less than $15 \%$. The TS value of the resulting OSBs ranged from 10.48-22.85\% (Fig. 4). The highest TS value was found in PF-bonded gmelina OSBs without steam treatment, while the lowest was found in MDI-bonded OSBs with steam treatment.

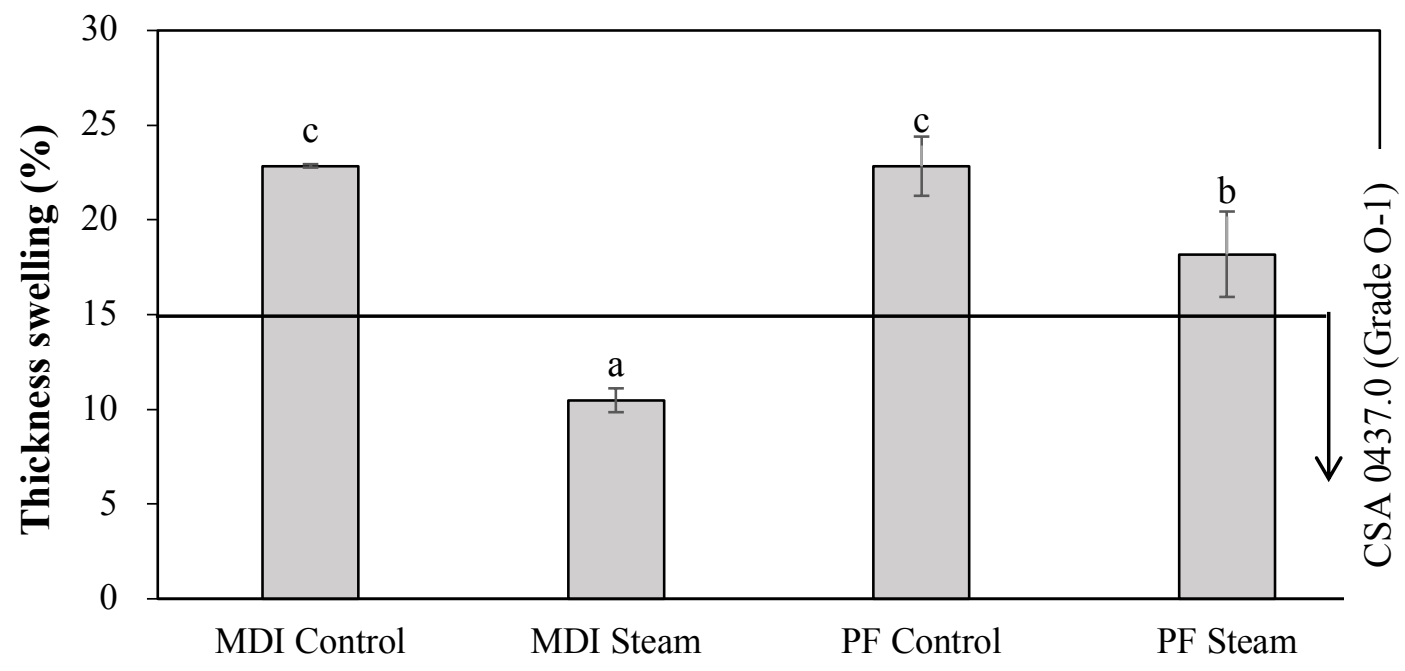

Treatment

Fig. 4. The thickness swelling value of gmelina OSBs on various treatments and adhesive types (Notes: different letters showed a significant difference). 
The ANOVA results showed that the interaction of steam treatment and the adhesive types significantly affected the TS value of gmelina OSBs. The TS values OSBs bonded by MDI were lower than those bonded by PF. The MDI adhesive is hydrophobic, absorbing less water and lowering thickness swelling in wood-based composite products (Adrin et al. 2013). Steam treatment also reduced the extractive content (Fatrawana et al. 2019); hence the adhesive is easier to penetrate strands. Greater adhesive penetration improves the bonding quality compared to the lower one, making water more difficult to enter the wood. Several studies also report that WA and TS values decreased after steam treatment on strands applied (Fatrawana et al. 2019; Maulana et al. 2016, 2017, 2019). The results showed that only gmelina OSBs bonded with MDI adhesive and steam-treated met the minimum requirement of CSA 0437.0 (Grade O-1) standard.

\subsection{Modulus of Elasticity}

The CSA 0437.0 (Grade O-1) standard requires a minimum value of MOE parallel to the grain direction of OSB of around 4,413 MPa. The value of MOE parallel to the grain direction of the OSBs ranged from 5,833-6,424 MPa (Fig. 5). The highest MOE parallel to the grain direction was found in MDI-bonded OSBs with steam treatment, while the lowest was in MDI-bonded OSBs without steam. The ANOVA results showed that only steam treatment significantly affected the MOE parallel to the grain direction.

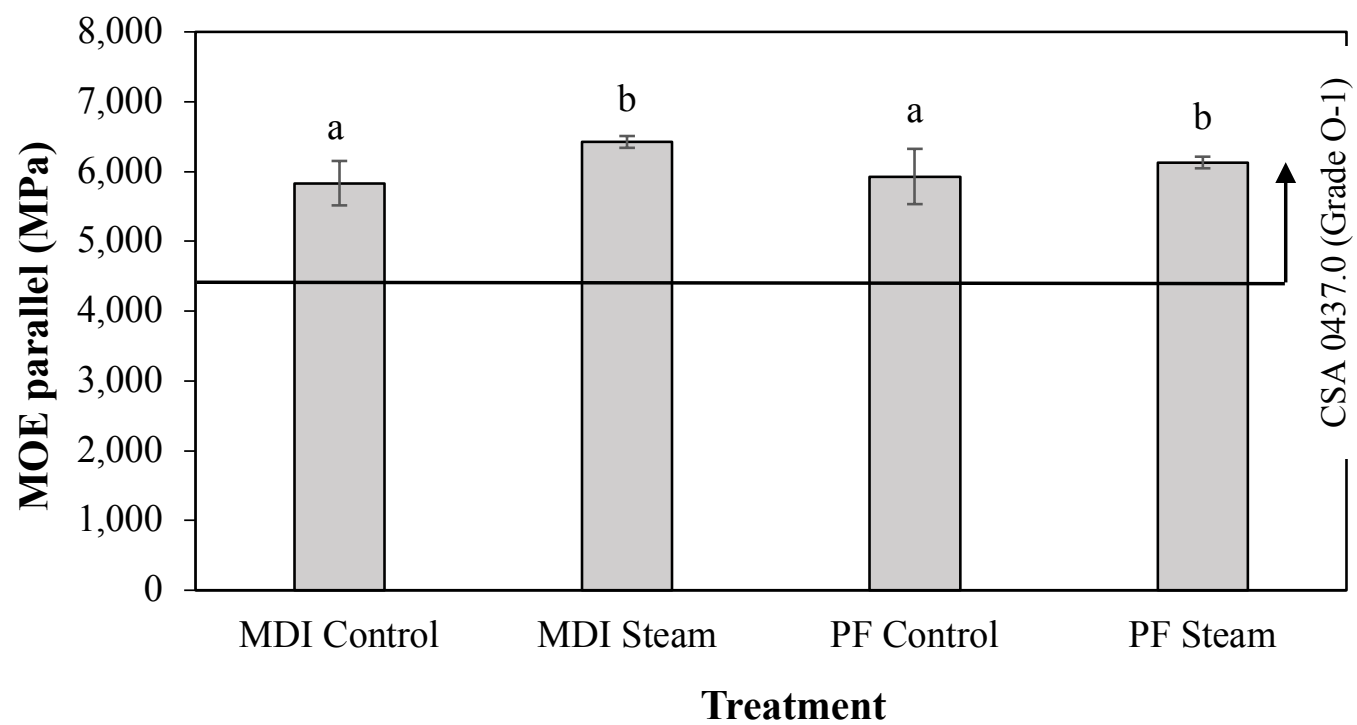

Fig. 5. The MOE parallel to the grain direction of gmelina OSBs on various treatments and adhesive types (Notes: different letters showed a significant difference).

The value of MOE perpendicular to the grain direction obtained ranged from 1,510-1,694 MPa (Fig. 6), showing higher values than the CSA 0437.0 (Grade O-1) standard of 1,275 MPa. The highest MOE perpendicular to the grain direction was found in MDI-bonded gmelina OSBs with steam treatment, while the lowest was found in MDI-bonded gmelina OSBs without steam. The results of ANOVA showed that the interaction of steam treatment and adhesive types affected the MOE perpendicular to the grain direction.

Gmelina OSBs with steam treatment had higher MOE parallel and perpendicular to the grain directions than gmelina OSBs control. The results of this study were similar to previous research that steam treatment could increase the MOE values of OSB (Fatrawana et al. 2019; Maulana et al. 2016, 2017, 2019). Steam treatment reduced the extractive content, resulting in better bonding 
quality and OSB strength (Fatrawana et al. 2019). The adhesive types also affected the MOE of the OSBs. The OSB bonded with MDI adhesive showed higher MOE than that bonded with PF resin. The results were similar to previous studies (Febrianto et al. 2009, 2015), showing excellent mechanical properties of OSB bonded with MDI adhesive. The MDI adhesive has greater adhesion strength than the PF resin, resulting in a better MOE value. All MOE parallel and perpendicular to the grain directions of gmelina OSBs in this study have met the minimum requirement of CSA 0437.0 (Grade O-1) standard.

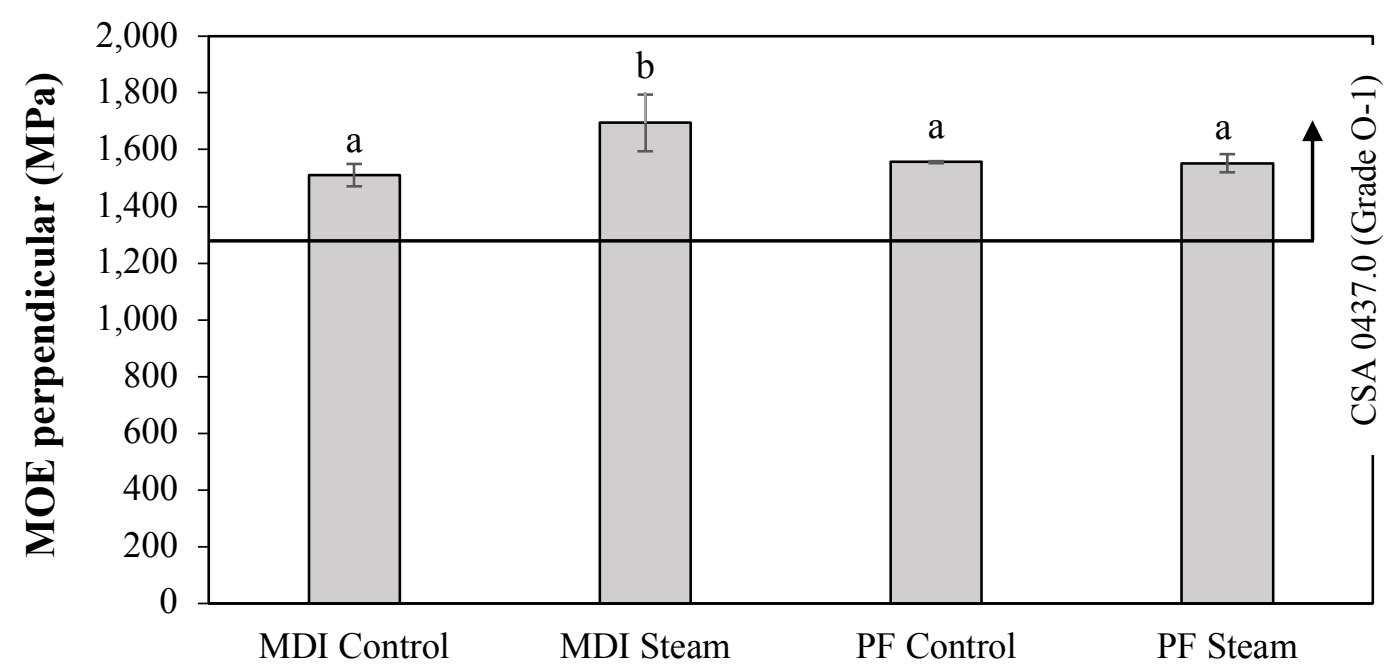

Treatment

Fig. 6. The MOE perpendicular to the grain direction of gmelina OSBs on various treatments and adhesive types (Notes: different letters showed a significant difference).

\subsection{Modulus of Rupture}

The value of MOR parallel to the grain direction of the OSBs ranged from 35-52 MPa (Fig. 7), higher than the minimum requirement of the CSA 0437.0 (Grade O-1) standard of $22.95 \mathrm{MPa}$.

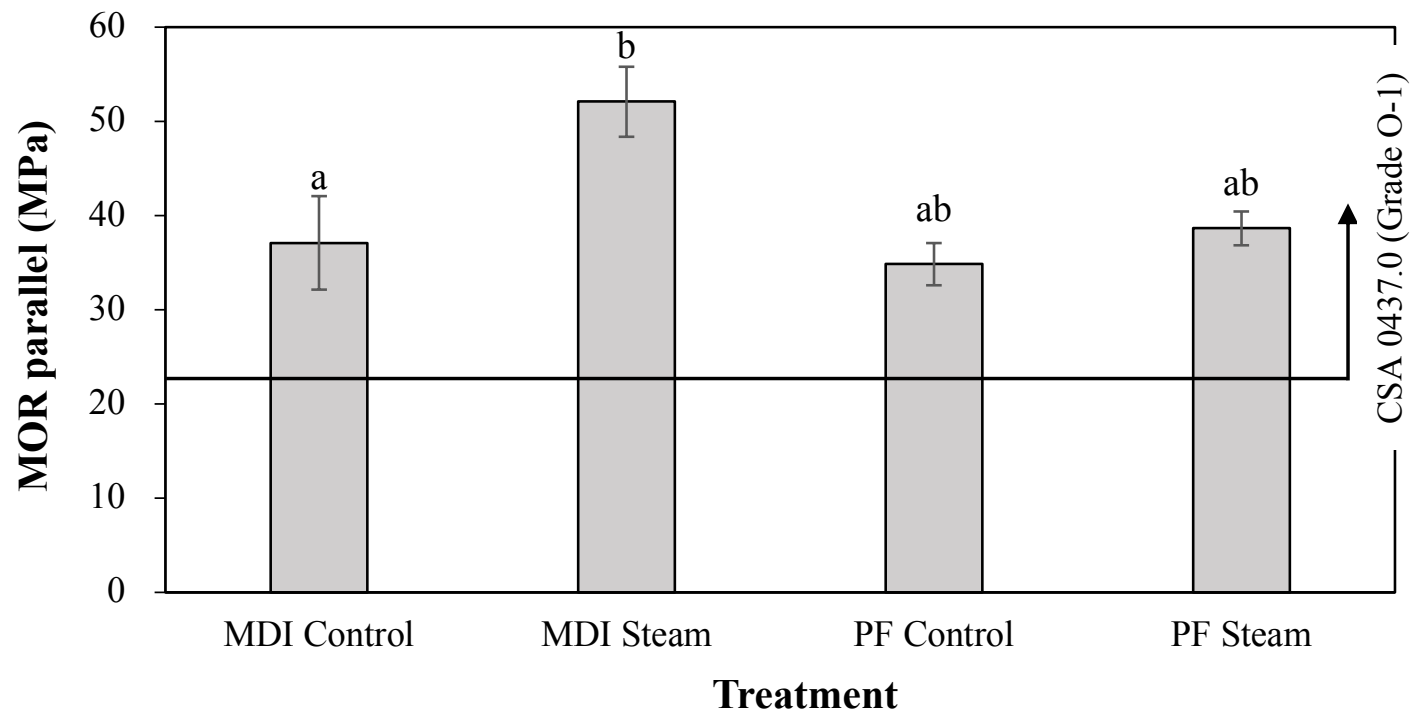

Fig. 7. The MOR parallel to the grain direction of gmelina OSBs on various treatments and adhesive types (Notes: different letters showed a significant difference). 
The CSA 0437.0 (Grade O-1) standard requires a minimum value of MOR perpendicular to the grain direction of OSB is $9.41 \mathrm{MPa}$. The MOR perpendicular to the grain direction of the OSBs ranged from 14-20 $\mathrm{MPa}$ (Fig. 8). The highest MOR perpendicular to the grain direction was found in PF-bonded gmelina OSBs with steam treatment, while the lowest was found in PF-bonded gmelina OSBs without steam.

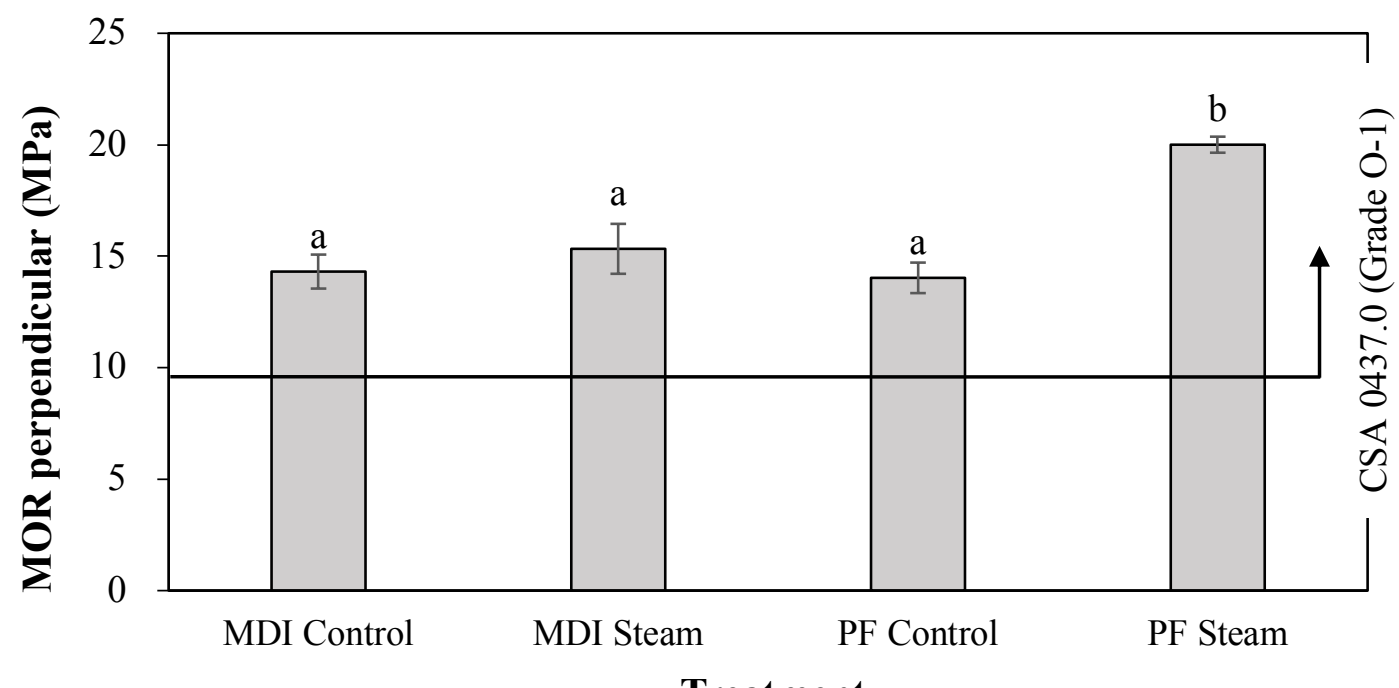

Treatment

Fig. 8. The MOR perpendicular to the grain direction of gmelina OSBs on various treatments and adhesive types (Notes: different letters showed a significant difference).

The ANOVA results showed that the interaction of steam treatment and adhesive types had a significant effect on the MOR value of OSB. Previous studies reported that steam treatment could increase the MOR value of the OSB (Fatrawana et al. 2019; Maulana et al. 2016, 2017, 2019). Fatrawana et al. (2019) stated that steam treatment could reduce extractive content and some starch. The reduction of extractive content caused better gluing, resulting in better mechanical properties of OSB. The use of different adhesives also affected the mechanical properties of the board. OSBs bonded with MDI adhesive have a higher MOR value than bonded with PF adhesive. This result was supported by Adrin et al. (2013), stating that OSB bonded with MDI adhesive have a higher MOR value than bonded with PF adhesive. Langenberg et al. (2010) stated that MDI adhesives chemically bond to wood via urethane linkages and produce high adhesion compared to PF adhesives which form weak mechanical interlocking and hydrogen bonds. All MOR values of the resulting OSBs parallel and perpendicular to the grain directions have met the minimum requirement of CSA 0437.0 (Grade O-1) standard.

\subsection{Internal Bonding Strength}

The CSA 0437.0 (Grade O-1) standard requires a minimum value of internal bonding (IB) strength of OSB of around $0.34 \mathrm{MPa}$. The IB value of the resulting OSBs ranged from $0.36-0.40$ MPa (Fig. 9). The highest IB value was found in MDI-bonded OSBs with steam treatment, while the lowest was in PF-bonded OSBs without steam. Based on the results of ANOVA, all factors did not have a significant effect on the IB value of gmelina OSBs. However, the IB value of gmelina OSBs with steam treatment tended to be higher than the control. This is because steam treatment could dissolve some extractive substances to improve the gluing process. In addition, steam treatment of wood fibers converts free sugars in wood into furan intermediates and then converted 
into furan resins, contributing to a better bonding process (Rowel et al. 2002). As a result, it increases the value of dimensional stability, flexural strength, and IB of OSB (Iswanto et al. 2010). Previous researches also showed that the IB value of OSB increased after steam treatment (Fatrawana et al. 2019; Maulana et al. 2016, 2017, 2019;). The adhesive types also affect the IB value of the OSBs. The OSB bonded with MDI adhesive has a higher IB value than that bonded with PF resin. The MDI adhesives chemically bond to wood via urethane linkages and produce high adhesion compared to PF adhesives which form weak mechanical interlocking and hydrogen bonds (Langenberg et al. 2010). This result was supported by Adrin et al. (2013), stating that OSB bonded with MDI adhesive has higher IB than bonded with PF adhesive. All IB values of gmelina OSBs obtained in this research have met the minimum requirement of the CSA 0437.0 (Grade O1) standard.

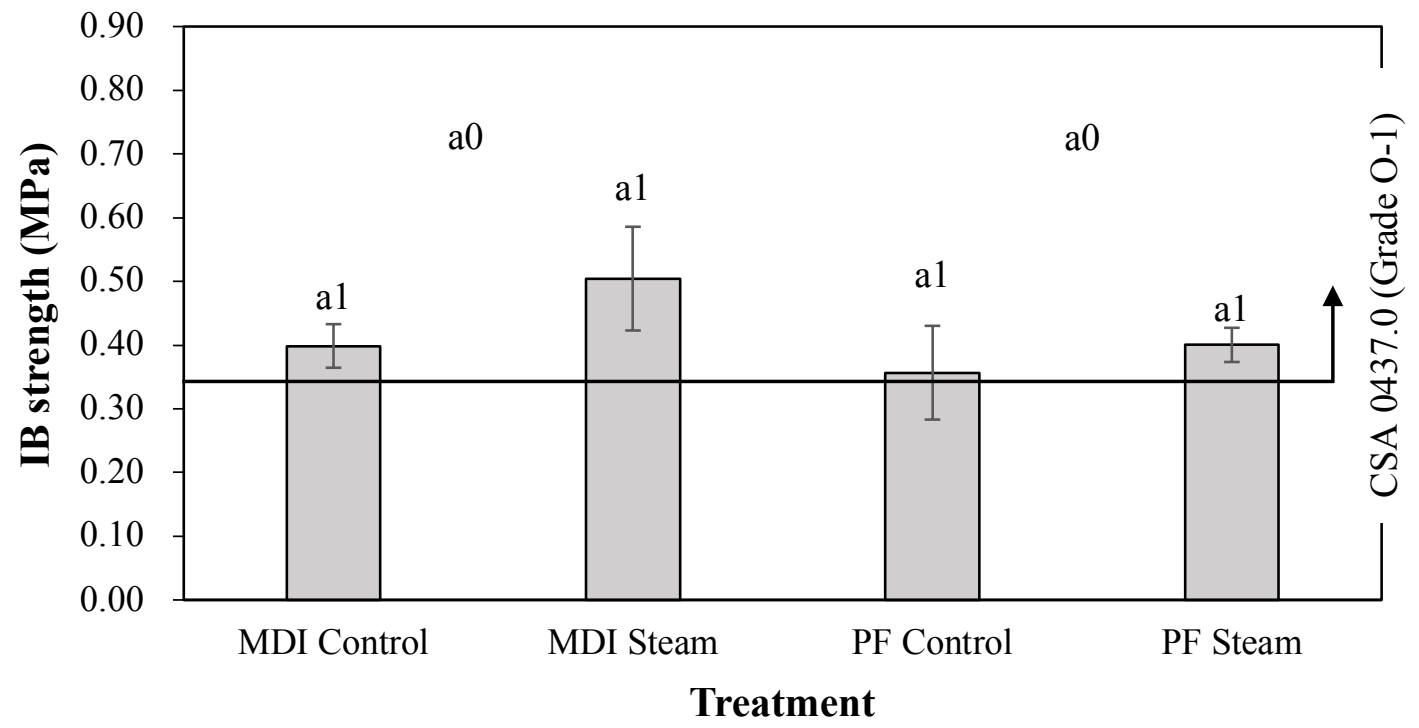

Fig. 9. The IB strength value of gmelina OSBs on various treatments and adhesive types (Notes: same letters showed no significant difference; 0: adhesive type, 1: pre-treatment).

\subsection{Screw Holding Power}

The value of screw holding power (SHP) of the resulting OSBs ranged from 82.71-89.61 kgf (Fig. 10). The highest SHP value was found in MDI-bonded OSBs with steam treatment, while the lowest was found in PF-bonded OSBs without steam. The ANOVA results showed that the steam treatment had a significant effect on the SHP value of OSB. The DMRT results showed that the steam treated OSB had a significantly different SHP value than the OSB control. Steam treatment can increase the adhesive bond with the strand. However, the use of different adhesives did not show significantly different results. The screw holding power is affected by moisture content, fiber orientation, specific gravity, method of screwing, dimensions, surface properties, and wood species used (Celebi and Kilic 2007). In addition, the IB value also affects the SHP value; the higher the IB value, the SHP value also increases (Wulandari et al. 2020). 


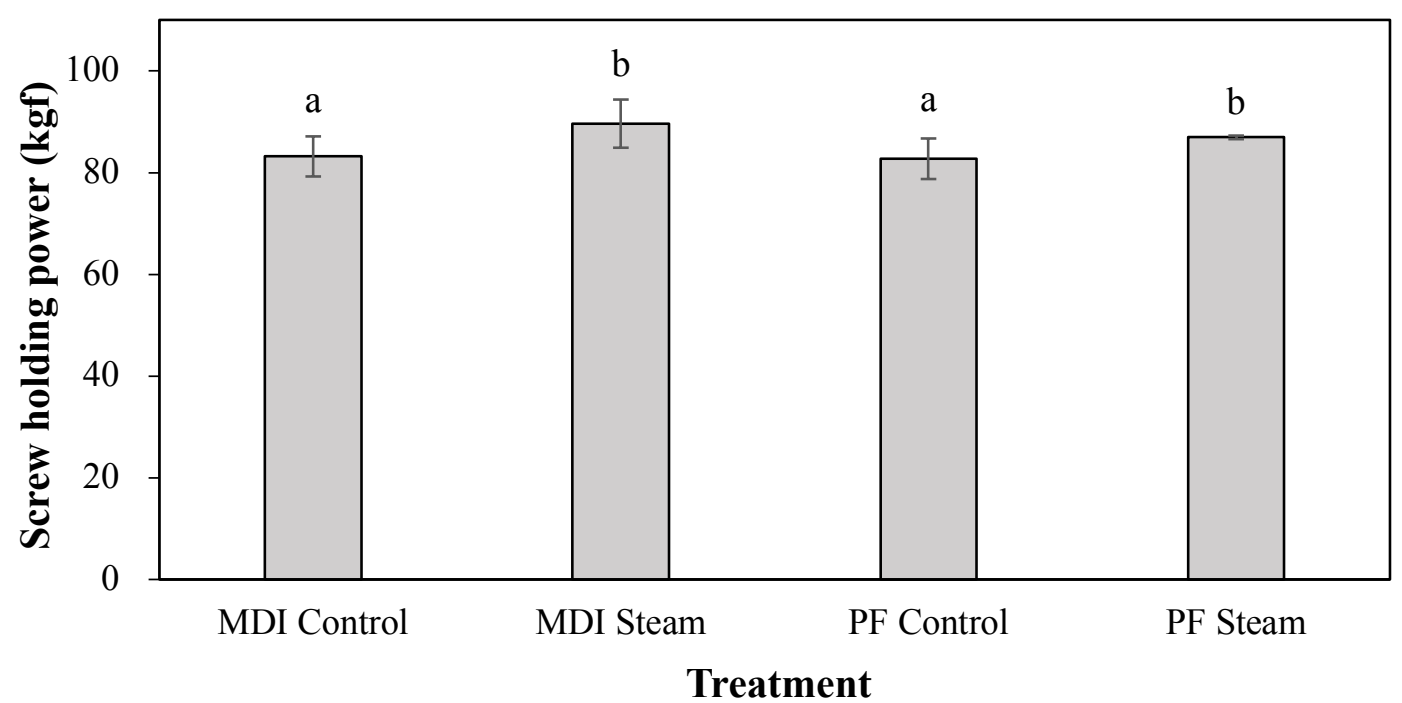

Fig. 10. The screw holding power of gmelina OSBs on various treatments and adhesive types (Notes: different letters showed a significant difference).

\section{Conclusions}

Steam treatment improved the quality of the physical and mechanical properties of gmelina OSBs by reducing the WA and TS and increasing the MOE, MOR, IB, and SHP. Both PF and MDI adhesives could be used to produce good-quality OSBs. The OSBs prepared with steam treatment and bonded with PF resin had mechanical properties that meet the standard CSA 0437.0 (Grade O-1), except for TS. The use of MDI adhesive resulted in better OSB than that bonded with PF resin. The OSBs prepared with steam treatment and bonded by MDI adhesive had physical and mechanical properties that meet CSA 0437.0 (Grade O-1) standard.

\section{Acknowledgments}

This research was funded by the Ministry of Research and Technology/National Research and Innovation Agency of Indonesia through Basic Research (2039/IT3.L1/PN/2021) and WCR (No. 2345/IT3.L1/PN/2021) grants.

\section{References}

Adrin, Febrianto, F., and Sadiyo, S. 2013. Properties of Oriented Strand Board Prepared from Steam-Treated Bamboo Strands under Various Adhesive Combinations. Jurnal Ilmu Teknologi Kayu Tropis 11(2): 109-119. DOI: 10.51850/jitkt.v11i2.89

APA. 2017. Oriented Strand Board. American Plywood Association (APA), The Engineer Wood Association, USA.

Celebi, G., and Kilic, M. 2007. Nail and Screw Withdrawal Strength of Laminated Veneer Lumber made up Hardwood and Softwood Layers. Construction and Building Materials 21: 894900. DOI: 10.1016/j.conbuildmat.2005.12.015

Davinsy, R., Satria, E. D., Maulana, M. I., Nawawi, D. S., Sari, R. K., Maulana, S., Hidayat, W., and Febrianto, F. 2019. Sifat Fisis dan Mekanis Oriented Strand Board Hibrida Bambu Pada Berbagai Shelling Ratio. Jurnal Ilmu dan Teknologi Kayu Tropis 17(2): 152-159. 
Fatrawana, A, Maulana, S., Nawawi, D. S., Sari, R. K., Hidayat, W., Park, S. H., Febrianto, F., Lee, S. H., and Kim, N. H. 2019. Changes in Chemical Components of Steam Treated Betung Bamboo Strands and Their Effects on the Physical and Mechanical Properties of Bamboo Oriented Strand Boards. European Journal of Wood and Wood Products 77: 731739. DOI: $10.1007 / \mathrm{s} 00107-019-01426-7$

Febrianto, F., Jang, J. H., Lee, S. H., Santosa, I. A., Hidayat, W., Kwon, J. H., and Kim, N. H. 2015. Effect of Bamboo Species and Resin Content on Properties of Oriented Strand Board Prepared from Steam-Treated Bamboo Strands. Bioresources 10(2): 2642-2655. DOI: 10.15376/biores. 10.2.2642-2655

Febrianto, F., Royama, L. I., Hidayat, W., Bakar, E. S., Kwon, J. H., and Kim, N. H. 2009. Development of Oriented Strand Board from Acacia Wood (Acacia mangium Wild): Effect of Pre-treatment of Strand and Adhesive Content on the Physical and Mechanical Properties of OSB. Journal of the Korean Wood Science and Technology 37(2): 121-127.

Febrianto, F., Sahroni, Hidayat, W., Bakar, E. S., Kwon, G. J., Kwon, J. H., Hong, S. I., and Kim, N. H. 2012. Properties of Oriented Strand Board made from Betung Bamboo (Dendrocalamus asper (Schultes.f) Backer ex Heyne). Wood Science Technology 46: 53-62. DOI: $10.1007 / \mathrm{s} 00226-010-0385-8$

Febrianto, F., Sumardi, I., Hidayat, W., Maulana, S. 2017. Papan Untai Bambu Berarah. IPB Press. Bogor, Indonesia.

Iswanto, A. H., Febrianto, F., Wahyudi, I., Hwang, W. J., Lee, S. H., Kwon, J. H., Kwon, S. M., Kim, N. H., and Kondo, T. 2010. Effect of Pre-treatment Techniques on Physical, Mechanical, and Durability Properties of Oriented Strand Board made from Sentang Wood. Journal of the Faculty of Agriculture, Kyushu University 55(2): 371-377.

JSA. 2003. JIS A 5908: Japanese Industrial Standard: Particle Board. Japanese Standard Association (JSA). Tokyo, Japan.

Kang, S., Fu, J., Zhang, G., Zhang, W., Yin, H., and Xu, Y. 2017. Synthesis of Humin-PhenolFormaldehyde Adhesive. Polymers 9(373): 1-10. DOI: 10.3390/polym9080373

Langenberg, K. V., Warden, P., Adam, C., and Milner, H. R. 2010. The Durability of IsocyanateBased Adhesives Under Service in Australian Conditions. The Results from a 3 Year Exposure Study and Accelerated Testing Regime (Literature Review). Australia: Forest and Wood Products Australia.

Lubis, M. A. R., Park, B. D., and Lee, S. M. 2019. Performance of Hybrid Adhesives of BlockedpMDI/Melamine-Urea-Formaldehyde Resins for the Surface Lamination on Plywood. Journal of the Korean Wood Science and Technology 47(2): 200-209. DOI: 10.5658/wood.2019.47.2.200

Maloney, T. M. 1993. Modern Particleboard and Dry-Process Fiberboard Manufacturing. San Fransisco: Miller Freeman Inc.

Maulana, S., Busyra, I., Fatrawana, A., Hidayat, W., Sari, R. K., Sumardi, I., Wistara, I. N. J., Lee, S. H., Kim, N. H., and Febrianto F. 2017. Effects of Steam Treatment on Physical and Mechanical Properties of Bamboo Oriented Strand Board. Journal Korean Wood Science Technology 45(6): 872-882. DOI: 10.5658/wood.2017.45.6.872

Maulana, S., Damanik, M. Q. A., Marwanto, Maulana, M. I., Fatrawana, A., Sumardi, I., Wistara, N. J., and Febrianto, F. 2019. Durability of Oriented Strand Board Prepared from SteamTreated Betung Bamboo to Natural Weathering. Jurnal Ilmu dan Teknologi Kayu Tropis 17(1): 34-46. DOI: 10.51850/jitkt.v17i1.459 
Maulana, S., Hidayat, W., Sumardi, I., Wistara, N. J., Maulana, M. I., Kim, J. H., Lee, S. H., Kim, N. H., and Febrianto, F. 2021. Properties of Dual-Species Bamboo-Oriented Strand Boards Bonded with Phenol Formaldehyde Adhesive under Various Compression Ratios. Bioresources 16(3): 5422-5435. DOI: 10.15376/biores.16.3.5422-5435

Maulana, S., Purusatama, B. D., Wistara, N. J., Sumardi, I., and Febrianto, F. 2016. Effect of Steam Treatment on Strand and Shelling Ratio on the Physical and Mechanical Properties of Bamboo Oriented Strand Board. Jurnal Ilmu dan Teknologi Kayu Tropis 14(2): 136-143. DOI: $10.51850 /$ jitkt.v14i2.206

Maulana, S., Sumardi, I., Wistara, N. J., Kim, N. H., and Febrianto, F. 2020. Effects of Compression Ratio on Physical and Mechanical Properties of Bamboo Oriented Strand Board. IOP Conference Series: Materials Science and Engineering 935: 012063. DOI: $10.1088 / 1757-899 x / 935 / 1 / 012063$

MOEF. 2021. Statistics 2019. Ministry of Environment and Forestry (MOEF). Jakarta, Indonesia. Moya, R. R., and Leandro, Z. L. 2010. Melina: Gmelina arborea Kunth. Verbenaceae. Technical sheet 5. In: Plantation Forest Wood Technology: Technical Sheets. Revista Forestal Mesoamericana Kuru 7(18-19): 87-101.

Nurhasni, Larasati, T. R. D., and Iksan, A. 2016. Delignification of Sawdust White Teak (Gmelina arborea Roxb.) by Fungi Phanerochaete chrysosporium Irradiated Gamma-Ray. Jurnal Kimia Valensi 2(2): 104-113. DOI: 10.15408/jkv.v2i2.3079

Prabawa, S. B. 2017. The Influence of Stem Position on Physical Properties and Fiber Dimension of Gmelina from Thinning Activity. Jurnal Ilmu Teknologi Kayu Tropis 15(1): 19-28. DOI: 10.51850/jitkt.v15i1.365

Rowel, R. M., Lange, S., McSweeny, and Davis, M. 2002. Modification of Wood Fiber using Steam. Proceeding of $6^{\text {th }}$ Rim Bio-Based Composites Symposium. Oregon, USA.

Riyanto, A. B., Patola, E., and Siswadi. 2013. Test of Dosage and Frequency of Urea Fertilizer Applications to Growth of White Teak Seedlings (Gmelina arborea Roxb.). Jurnal Inovasi Pertanian 12(2): 1-13.

SBA. 2005. Oriented Strand Board in Wood Frame Construction. Structural Board Association (SBA). Ontario, Canada.

Statistics Indonesia. 2020. Statistics of Forestry Production 2019. Statistics Indonesia. Jakarta, Indonesia.

Sutrisno, Purwasasmita, B. S., Alamsyah, E. M., and Syamsudin, T. S. 2015. Synthesis, Characterization and Functionalization of Bio-Based Nano Filler made from Ash Resulted from Wood Waste Burning to Reduce Formaldehyde Emission of Bio-Composite Products. Journal of Research and Development on Nanotechnology 2(1): 1-19.

Wulandari, T., Asri, A., Faryuni, I. D. 2020. Physical and Mechanical Properties of Cocoa Pod Peel Waste Particle Board Reinforced with Jabon Wood. Prisma Fisik 8(1): 33-39. DOI: 10.26418/pf.v8i1.40163 